\title{
Centrosomal Protein of 170 kDa Protein B
}

National Cancer Institute

\section{Source}

National Cancer Institute. Centrosomal Protein of 170 kDa Protein B. NCI Thesaurus.

Code C126613.

Centrosomal protein of $170 \mathrm{kDa}$ protein $\mathrm{B}(1589 \mathrm{aa}, \sim 172 \mathrm{kDa})$ is encoded by the human CEP170B gene. This protein may be involved in microtubule dynamics. 